\title{
Preface: Research and Management for the Conservation of Coastal Lagoon Ecosystems, South-North Comparisons
}

\author{
Rutger de Wit • Nabila Mazouni • \\ Pierluigi Viaroli
}

(C) Springer Science+Business Media B.V. 2012

Coastal lagoons are aquatic ecosystems that share many features with estuaries, where seawater mixes with freshwater from continental origin, and also bear resemblances with shallow lakes as they often occur as shallow water bodies separated from the ocean by a barrier and are usually oriented parallel to the coastline (Kjerfve, 1994). The latter aspect may explain why in the vernacular languages of South France, Italy, and Spain the same word is used both for lagoons and for shallow lakes. On a global scale, these systems comprise $13 \%$ of world coastlines (Barnes, 1980) and $5.3 \%$ of the European coastlines. The SE

Guest editors: R. de Wit, N. Mazouni \& P. Viaroli / Research and Management for the Conservation of Coastal Lagoon Ecosystems: South - North Comparisons

R. de Wit $(\square)$

"Ecologie des Systèmes marins côtiers (Ecosym)". UMR 5119, Université Montpellier 2, CNRS, IRD, Ifremer, Université Montpellier 1, Montpellier, France

e-mail: rutger.de-wit@univ-montp2.fr

R. de Wit

Coastal Research and Planning Institute, Klaipeda

University, Klaipeda, Lithuania

\section{N. Mazouni}

UMR-Ecosystèmes Insulaires Océaniens, Université de la Polynésie Française, Faa'a, Tahiti, French Polynesia

P. Viaroli

Department of Environmental Sciences, Parma

University, Parma, Italy coast of the Baltic Sea and the Atlantic and Mediterranean coasts of Southern Europe represent the major lagoon regions in Europe. The coastlines of the Mediterranean Sea comprise about six hundred lagoons that are listed by the Transitional Water Data Platform developed within the CIRCLEMED project ClimBioMedNet (www.circlemednet.unisalento.it). Some important hydrological, geomorphological, and biodiversity aspects of North African lagoons have been described in a special Hydrobiologia issue (Thomson \& Flower, 2009).

In the 1980s, the European research on coastal lagoons was focused on describing the geomorphology, hydrology, and ecological classification criteria, while during the 1990s it broadened in scope to include more functional ecology and biogeochemistry (Viaroli et al., 2005a). During the first decade of the 21 st century, the coastal lagoon research has even further broadened in scope and now comprises a large panel of disciplines, including environmental economics, sociology, history, and politicology in addition to the natural sciences. The enforcement of the Water Framework Directive also stimulated a new effort in synthesizing knowledge and developing future research (Basset et al., 2005; Zaldivar et al., 2008; Tagliapietra et al., 2009).

Some integrated projects have succeeded in developing successful interdisciplinary collaborations to tackle important questions about reconciling biodiversity conservation with human uses of lagoons, while placing the lagoons in the context of the aquatic 
continuum. An example of such an integrative multidisciplinary approach is the DITTY project (Development of an information technology tool for the management of Southern European lagoons under the influence of river-basin runoff lagoon uses, www.ditty project.org; e.g., Aliaume et al., 2007). Coastal lagoon ecosystems are particularly vulnerable to global change (Viaroli et al., 2007). Climate change is predicted to impact the temperature and salinity regimes in coastal lagoons. Coastal lagoons are also vulnerable to relative sea level rise. Rising sea level and increasing erosion of barriers may result in conversion of the lagoon in an open bay. But, in many natural lowland landscapes, the barriers and lagoons may move inward during sea level rise. However, the inward moving of the lagoons is often hampered by man-made structures to protect the land from flooding and by the urbanization of the shoreline both on the barrier and interior shore of the lagoon (Flemer \& Champs, 2006). Hence, coastal lagoons may be reduced in size and peripheral wetlands may be lost by coastal squeeze (Doody, 2004).

The "4th European Conference on Coastal Lagoon Research; Research and Management for the conservation of coastal lagoon ecosystems: South-North comparisons" was the fourth in a series of biannual conferences focused on the scientific research on coastal lagoons and the management for their conservation and sustainable use. The first European lagoon conferences took place in 2003 in Ferrara, Italy, which focused on Southern European lagoons, mainly on the Northern shore of the Mediterranean and the Atlantic lagoons of the Iberian Peninsula. A pan-European scale has been adopted since the second conference that took place in Klaipeda, Lithuania. Both conferences have given rise to special issues of Hydrobiologia (Viaroli et al., 2005b; Razinkovas et al., 2008). The third conference was organized in Naples, Italy. The specific aim of the fourth conference was to improve the exchanges, between scientists and managers, and between Northern and Southern countries, for the conservation of coastal lagoons and the sustainable use of their natural resources. Three hundred twenty participants from 23 different counties attended this conference. Among them, many lagoon managers, other end-users of lagoon studies, and many participants from North-African countries (Tunisia, Morocco, Algeria) actively contributed oral and poster presentations showing that our aim to involve managers and end-users and adopt a Euro-Mediterranean approach was very successful.

The practice of lagoon management and lagoon uses creates an important demand for scientific research of these particular aquatic systems. The planning of the sessions had been discussed with lagoon managers and other end-users of lagoon studies in the LanguedocRoussillon region to identify the issues that were of particular interest to them. These end-users formulated a very clear demand for organizing two mini-symposia on the issues of biodiversity conservation and emerging questions about the impacts of contaminants, which were titled, respectively, "Drivers of the biodiversity in lagoon ecosystems in the perspective of global change" and "Persistent Organic Pollutants in the aquatic continuum; How to protect the lagoons against pesticides and other pollutants?" This special Hydrobiologia issue is accompanied by a special issue of Estuarine Coastal Shelf Science (Mazouni \& De Wit, in press) that presents a selection of papers from this conference focusing on the interface between science and management. This special Hydrobiologia issue focuses on studies of the natural processes including (1) benthic biota and their impact on sediment biogeochemistry particularly to understand how water quality is impacted by benthic processes; (2) drivers of the biodiversity in lagoon ecosystems in the perspective of global change; (3) impacts of climate variability and sea level rise on the geomorphology and ecosystem functioning of coastal lagoons.

Four papers in this issue deal with the ecology of Magnoliophyta (higher plants with roots) in coastal lagoons and the role of this aquatic vegetation for the biogeochemistry and ecosystem processes. Seagrasses are ecosystem engineers and particularly important for sustaining the biodiversity in lagoons, but are also very vulnerable to eutrophication. Hence, seagrasses have been disappearing from coastal systems, including coastal lagoons, at accelerating rates since the 1980s (Waycott et al., 2009). The review by Yamamuro (2012, this issue) describes that in Japanese coastal lagoons, the shifts of primary producers from rooted Magnoliophyta to phytoplankton occurred early, i.e., between the mid-1950s and 1965, most likely because of the wide use of herbicides for rice paddies in the watersheds of these lagoons. Hence, the toxic herbicides provoked loss of seagrasses even before achieving the eutrophication levels that are detrimental for the seagrasses. Her historic analyses showed how 
extraction of seagrass biomass for use as fertilisers corresponded to extraction of about $10 \%$ of the annual nitrogen loading to the Japanese lagoons. It has often been considered that most of the primary production of seagrasses feeds a detritus food chain and there is only scarce data on seagrass herbivory. Fernandez et al. (2012, this issue) studied the importance of herbivory of the seagrass Cymodocea nodosa by sea urchins (Paracentrotus lividus) in a Mediterranean coastal lagoon. They showed when densities of this sea urchin are low these animals consume $<20 \%$ of the $C$. nodosa production. However, active movement of these consumers among adjacent habitats resulted in sea urchin feeding fronts (with densities of 10-98 ind. $\mathrm{m}^{-2}$ ) that overgraze by consuming all standing above-ground biomass and thus temporarily grazing rates exceeded the seagrass production rates. Obrador and Pretus (2012, this issue) analyzed in detail the cycling of organic and inorganic carbon in a brackish Mediterranean lagoon and showed that they are mainly driven by the wax and wane of the Magnoliophyta Ruppia cirrhosa and Potamogeton pectinatus. Finally, De Wit et al. (2012, this issue) studied the interactions between phytoplankton and the intertidal seagrass Zostera noltii in a mesotidal Atlantic lagoon.

Two papers deal in more detail with the biogeochemical processes in the sediment and how these impact the chemistry of the water column through sediment water exchanges. Delgard et al. (2012, this issue) studied the porewater composition and the dynamics of sediment profiles in permeable sediments of intertidal flats of a mesotidal Atlantic lagoon. They found that the oxygen dynamics in the upper sediment at low tide appeared to be mainly controlled by microphytobenthos activity, while tidal forcing seemed to influence the oxygen dynamic in a minor way through flushing of the uppermost sediment porewater layer at the beginning and end of immersion. Zilius et al. (2012, this issue) monitored total and diffusive oxygen fluxes during a 9-month ice-free period in the sediments of the Curonian Lagoon on the Baltic Sea, which is the largest lagoon in Europe $\left(1,500 \mathrm{~km}^{2}\right)$. Total sedimentary oxygen uptake varied by a factor of 8 , from a minimum in March after melting of the ice to a maximum in July, likely due to higher temperatures and accumulation of labile organic matter after sedimentation of micro-algal and cyanobacterial blooms.
We called for papers on South-North comparisons, but we were not very successful in this respect. For the conference we received, however, an impressive amount of oral and poster contributions on biodiversity and ecosystem processes of the lagoons of the Southern shore of the Mediterranean Sea from colleagues in Tunisia, Algeria, and Morocco. A selection of papers presented at the conference that describe different aspects of biodiversity in NorthAfrican lagoons will be published in a special issue of Transitional Waters Bulletin (De Wit \& Viaroli, in prep). Nevertheless, Povilanskas et al. (2012, this issue) made coherent South-North comparisons, i.e., between the Lesina lagoon on the Adriatic Sea and the Curonian lagoon on the Baltic Sea, in the South and North of Europe, respectively. These authors studied geographical aspects of linear littoral habitats, including integrity and fragmentation, in order to describe the "coastal squeeze" effect. These authors found that on the barrier of Lesina lagoon the dune slack ponds and the strip of glasswort (Salicornia spp.) swards, which showed highest integrity, both depended upon climatic conditions that determined the shape of the salinity gradient. The chain of shifting coastal dunes and the reed beds of the Curonian Spit depended upon the long-shore dynamics of water and sediment flows. Finally, Hamdi \& Charfi-Cheikhrouha (2012, this issue) evaluate the role of Tunisian coastal lagoons for overwintering waterfowl to support effective conservation measures (Ramsar sites). Every year 76 species were observed and on average more than 120,000 individuals of these species counted, which represent more than $25 \%$ of the national population size. In conclusion, the conference was particularly instrumental for initiating enhanced collaboration between European and North-African scientists that is very promising for addressing the issue of South-North comparisons in the Mediterranean Sea in the near future.

Acknowledgments The conference was organized and financially supported by the University of Montpellier (Université Montpellier 2) in collaboration with the Cepralmar. The regional government of the Region Languedoc-Roussillon and the Agence de l'Eau are acknowledged for generous financial contributions. Other important financial contributions were obtained from the Centre National de la Recherche Scientifique (CNRS), Ifremer, PNEC Chantier Lagunes méditerranéennes, the Ministry of Ecology, Energy, Sustainable Development and the Sea (MEEDM), LOICZ, the Institut de Recherche pour le Développement (IRD), BRGM, the 
Department of Hérault, Montpellier Agglomération, the city of Montpellier, Université Montpellier 1 and the Agence Universitiare de la Francophonie. We acknowledge Marc Barral (Region Languedoc-Roussillon) and Laurent Moragues (Agence de l'Eau Rhône-Méditerranée-Corse) for strongly supporting our aim of more strongly linking the science and management of coastal lagoons. Finally, we thank the International Scientific Committee of the conference and the anonymous reviewers who were very helpful for defining the program and evaluating and editing the manuscripts.

\section{References}

Aliaume, C., P. Viaroli, J. M. Zaldivar \& T. Do Chi, 2007. Coastal lagoons of Southern Europe: recent changes and future scenarios. Transitional Waters Monographs 1: 1-12.

Barnes, R. S. K., 1980. Coastal lagoons; the natural history of a neglected habitat. Cambridge University Press, Cambridge.

Basset, A., L. Sabetta, A. Fonnesu, D. Mouillot, T. Do Chi, P. Viaroli, G. Giordani, S. Reizopoulou, M. Abbiati \& G. C. Carrada, 2005. Typology in Mediterranean transitional waters: new challenges and perspectives. Aquatic Conservation: Marine and Freshwater Ecosystems 16: 441-455.

De Wit, R., M. Troussellier, C. Courties, E. Buffan-Dubau \& E. Lemaire, 2012. Short-term interactions between phytoplankton and intertidal seagrass vegetation in a coastal lagoon (Bassin d'Archachon, SW France). Hydrobiologia (this issue). doi:10.1007/s10750-012-1153-6.

Delgard, M.L., B. Deflandre, E. Metzger, D. Nuzzio, S. Capo, A. Mouret \& P. Anschutz, 2012. In situ study of short-term variations of redox species chemistry in intertidal permeable sediments of the Arcachon lagoon. Hydrobiologia (this issue). doi:10.1007/s10750-012-1154-5.

Doody, J. P., 2004. 'Coastal squeeze' - an historical perspective. Journal of Coastal Conservation 10(1-2): 129-138.

Fernandez, C., L. Ferrat, G. Pergent \& V. Pasqualini, 2012. Sea urchin-seagrasses interactions: trophic links in a benthic ecosystem from a coastal lagoon. Hydrobiologia (this issue). doi:10.1007/s10750-012-1151-8.

Flemer, D. A. \& M. A. Champ, 2006. What is the future of estuaries given nutrient over-enrichment, freshwater diversion and low flows? Marine Pollution Bulletin 52: 247-258.

Hamdi, N. \& F. Charfi-Cheikhrouha, 2012. Characterization of the waterbird communities wintering in Tunisian coastal lagoons. Hydrobiologia (this issue). doi: 10.1007/s10750012-1157-2.

Kjerfve, B. (ed.), 1994. Coastal Lagoon Processes. Elsevier Oceanography Series 60. Elsevier, Amsterdam: 577 pp.
Obrador, B. \& J. L. Pretus, 2012. Budgets of organic and inorganic carbon in a Mediterranean coastal lagoon dominated by submerged vegetation. Hydrobiologia (this issue). doi: 10.1007/s10750-012-1152-7.

Povilanskas, R., A. Armaitienė, P. Breber, A. RazinkovasBaziukas \& J. Taminskas, 2012. Integrity of linear littoral habitats of Lesina and Curonian lagoons. Hydrobiologia (this issue) doi:10.1007/s10750-012-1156-3.

Razinkovas, A., Z. Gasiūnaite, P. Viaroli \& J. M. Zaldívar, 2008. European lagoons - need for further comparison across spatial and temporal scales. Hydrobiologia 611: $1-179$.

Tagliapietra, D., M. Sigovini \& A. Volpi Ghirardini, 2009. A review of terms and definitions to categorize estuaries, lagoons and associated environments. Marine and Freshwater Research 60: 497-509.

Thomson, J. R. \& R. J. Flower (eds), 2009. North African coastal lagoons. Hydrobiologia 622: 1-232.

Viaroli, P., M. Mistri, M. Troussellier, S. Guerzoni \& A. C. Cardoso, 2005a. Preface: Structure, functions and ecosystem alterations in Southern European coastal lagoons. Hydrobiologia 550: vii-ix.

Viaroli P., M. Mistri, M. Troussellier, S. Guerzoni \& A. C. Cardoso (eds), 2005b. Structure, functions and ecosystem alterations in Southern European coastal lagoons. Hydrobiologia 550: 1-269.

Viaroli P., P. Lasserre \& P. Campostrini (eds), 2007. Lagoon and coastal wetlands in the global change context: impacts and management issues. Hydrobiologia 577: 1-168.

Waycott, M., C. M. Duarte, T. J. B. Carruthers, R. J. Orth, W. C. Dennison, S. Olyarnik, A. Calladine, J. W. Fourqurean, K. L. Heck Jr, A. R. Hughes, G. A. Kendrick, W. J. Kenworthy, F. T. Short \& S. L. Williamse, 2009. Accelerating loss of seagrasses across the globe threatens coastal ecosystems. Proceedings of the National Academy of Sciences 106: $12377-12381$.

Yamamuro, M., 2012. Herbicide-induced macrophyte-to-phytoplankton shifts in Japanese lagoons during the last fifty years: consequences for ecosystem services and fisheries. Hydrobiologia (this issue). doi:10.1007/s10750-012-11 50-9.

Zaldivar, J. M., A. C. Cardoso, P. Viaroli, A. Newton, R. De Wit, C. Ibañez, S. Reizopoulou, F. Somma, A. Razinkovas, A. Basset, M. Holmer \& N. Murray, 2008. Eutrophication in transitional waters: an overview. Transitional Waters Monographs 2: 1-78.

Zilius, M., M. Bartoli, D. Daunys, R. Pilkaityte \& A. Razinkovas, 2012. Patterns of benthic oxygen uptake in a hypertrophic lagoon: spatial variability and controlling factors. Hydrobiologia (this issue). doi:10.1007/s10750-012-1155-4. 